\title{
NKX2-6 mutation predisposes to familial atrial fibrillation
}

\author{
JUN WANG ${ }^{1,2}$, DAI-FU ZHANG ${ }^{1}$, YU-MIN SUN ${ }^{2}$, RUO-GU LI ${ }^{3}$, XING-BIAO QIU ${ }^{3}$, \\ XIN-KAI QU ${ }^{3}, \mathrm{XU} \mathrm{LIU}^{3}$, WEI-YI FANG ${ }^{3}$ and YI-QING YANG ${ }^{3-5}$

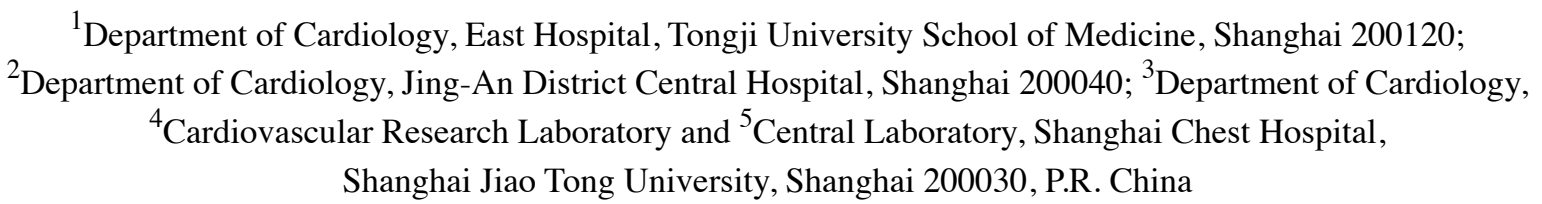

Received May 31, 2014; Accepted October 10, 2014

DOI: $10.3892 / \mathrm{ijmm} .2014 .1971$

\begin{abstract}
Atrial fibrillation (AF) is the most common form of sustained cardiac arrhythmia and is associated with substantially increased morbidity and mortality rates. Aggregating evidence demonstrates that genetic defects are involved in the pathogenesis of $\mathrm{AF}$ and a number of $\mathrm{AF}$-associated genes have been identified. Nevertheless, AF is a genetically heterogeneous disorder and the genetic components underpinning $\mathrm{AF}$ in an overwhelming majority of patients remain unclear. In this study, the entire coding exons and splice junction sites of the NK2 homeobox 6 (NKX2-6) gene, which encodes a homeodomain transcription factor important for cardiovascular development, were sequenced in 150 unrelated patients with lone AF, and a novel heterozygous NKX2-6 mutation, p.Q175H, was identified in an index patient. Genetic analysis of the available family members of the mutation carrier revealed that the mutation co-segregated with AF transmitted in an autosomal dominant pattern. The missense mutation was absent in the 200 unrelated ethnically matched healthy individuals used as controls and the altered amino acid was completely conserved evolutionarily among species. Due to unknown transcriptional targets of NKX2-6, the functional characteristics of the mutation as regards transcriptional activity were analyzed using NKX2-5 as a surrogate. Alignment between human NKX2-6 and NKX2-5 proteins displayed that the Q175H-mutant NKX2-6 was equivalent to the Q181H-mutant NKX2-5, and the
\end{abstract}

Correspondence to: Professor Dai-Fu Zhang, Department of Cardiology, East Hospital, Tongji University School of Medicine, 150 Jimo Road, Shanghai 200120, P.R. China

E-mail: zhangdaifu69@sina.cn

Professor Yi-Qing Yang, Department of Cardiology, Cardiovascular Research Laboratory and Central Laboratory, Shanghai Chest Hospital, Shanghai Jiao Tong University, 241 West Huaihai Road, Shanghai 200030, P.R. China

E-mail: yang99yang66@hotmail.com

Key words: atrial fibrillation, genetics, transcription factor, NKX2-6, reporter gene assays introduction of Q181H into NKX2-5 significantly decreased its transcriptional activity at the atrial natriuretic factor promoter. The present study firstly associates genetically defective NKX2-6 with enhanced susceptibility to AF, providing novel insight into the molecular mechanisms underlying AF and suggesting potential strategies for the antenatal prophylaxis and personalized treatment of $\mathrm{AF}$.

\section{Introduction}

Atrial fibrillation (AF), a supraventricular tachyarrhythmia characterized by chaotic atrial electrical activity and consequently ineffective atrial contraction, is the most common type of cardiac arrhythmia observed in clinical settings, accounting for approximately one-third of hospitalizations for cardiac rhythm disturbances (1). The prevalence of AF is approximately $1 \%$ in the general population, and increases strikingly with advancing age, rising from $>1 \%$ in subjects under 60 years of age to nearly $10 \%$ in individuals aged over 80 years (2). According to a report from the Framingham Heart Study, individuals older than 40 years have an approximately $25 \%$ chance of developing AF during their lifetime (3). The number of individuals with AF in the United States is presently estimated at 2.3 million and is projected to exceed 15.9 million by the year 2050 , mainly due to the aging population and improved cardiovascular survival (4). The condition is associated with severe complications, such as chronic heart failure and stroke, significantly contributing to cardiovascular morbidity and mortality. Compared to sinus rhythm, AF confers a 2-fold increased risk of death (5) and a 5 -fold increased risk of thromboembolic stroke (6). Of note, the annual incidence of ischemic stroke resulting from AF increases considerably with age, ranging from $1.5 \%$ of adults in their fifties to $23.5 \%$ in octogenarians (6). Additionally, AF may result in a degraded quality of life, reduced exercise tolerance, cognitive dysfunction or dementia, worsened renal function, tachycardiainduced cardiomyopathy, myocardial infarction and left ventricular dysfunction or even congestive heart failure (7-16). Therefore, AF represents an increasing public health challenge with profound socioeconomic implications. The appraised cost of treatment for $\mathrm{AF}$ is $<1 \%$ of the health care expenditure (17) and only in the United States, the direct costs of treating nonvalvular AF are in excess of $\$ 6.4$ billion per year (18). Despite 
the high prevalence and substantial clinical significance, the molecular basis underlying AF remains largely unclear.

AF often occurs secondary to various cardiovascular and systemic diseases and surgical procedures, such as coronary artery disease, congenital heart disease, valvular heart disease, cardiac surgery, cardiomyopathy, myocarditis, pulmonary heart disease, left ventricular dysfunction, hypertension, hyperthyroidism, diabetes mellitus and electrolyte imbalance. Other potential risk factors responsible for the development of AF include age, male gender, obesity, high-level physical training, prehypertension, increased pulse pressure, diastolic dysfunction, obstructive sleep apnea, hyperuricemia, kidney disease, systemic inflammation, pericardial fat, tobacco use and alcohol consumption (19-23). However, in 30-45\% of the total number of patients, AF is diagnosed in the absence of the above-mentioned associated diseases or predisposing factors, a condition referred to as idiopathic $\mathrm{AF}$ or lone $\mathrm{AF}$, and up to $15 \%$ of these patients with lone AF have a clearly established positive family history, and are thus defined as familial AF (1). Aggregating epidemiological studies have demonstrated the pronounced clustering of AF in families and the markedly increased incidence of AF in the close relatives of AF patients, indicating a pivotal role of genetic factors in the pathogenesis of familial AF (24-31). In previous studies, genome-wide genetic linkage analysis with highly polymorphic microsatellite markers mapped AF-susceptibility loci on human chromosomes 10q22-24, 11p15.5, 6q14-16, 5p13, 10p11-q21 and 5p15, of which AF-causing mutations in 2 genes, including potassium voltage-gated channel, KQT-like subfamily, member 1 (KCNQ1) on chromosome 11p15.5 and nucleoporin $155 \mathrm{kDa}(N U P 155)$ on chromosome $5 \mathrm{p} 13$, were identified and functionally deciphered (32-37). The direct analysis of candidate genes has identified an increasing number of AF-related genes, including potassium voltage-gated channel, Isk-related family, member 1 (KCNE1-5), potassium voltage-gated channel, subfamily $\mathrm{H}$ (eag-related), member $2(K C N H 2)$, potassium voltage-gated channel, shaker-related subfamily, member 5 (KCNA5), potassium voltage-gated channel, Shal-related subfamily, member 3 (KCND3), potassium inwardly-rectifying channel, subfamily $\mathbf{J}$ (KCNJ2), KCNJ8, gap junction protein, alpha 1, $43 \mathrm{kDa}(G J A 1)$, gap junction protein, alpha $5,40 \mathrm{kDa}(G J A 5)$, atrial natriuretic peptide $(A N P)$, sodium channel, voltage-gated, type $\mathrm{V}$, alpha subunit (SCN5A) and sodium channel, voltage-gated, type I, beta subunit $(S C N 1 B-4 B)$ (38-63). Nevertheless, these well established AF-associated genes only explain a small fraction of cases of AF, and in an overwhelming majority of patients, the genetic determinants for AF remain unknown.

Recent studies indicate that abnormal embryonic development and structural remodeling of the cardiovascular system, particularly the pulmonary veins and the atria, create a major anatomic substrate liable to AF $(64,65)$. A growing body of evidence substantiates the crucial role of several cardiac transcription factors, including NK2 homeobox (NKX2)-5, GATA binding protein (GATA)4, GATA5, GATA6 and paired-like homeodomain 2 (PITX2)c in normal cardiovascular morphogenesis (66-87), and multiple mutations in these transcription factors have been causally linked to AF (88-101). NKX2-6 is another member of the NK2-family of transcription factors and its expression profile and functional roles partially overlap with those of NKX2-5 during cardiovascular development (102-
105), which warrants the screening of $N K X 2-6$ as a preferred candidate gene for the development of AF.

\section{Materials and methods}

Study subjects. A cohort of 150 unrelated patients with lone AF was enrolled from the Han Chinese population. The available relatives of the index patients were also recruited. A total of 200 ethnically-matched unrelated healthy individuals were enlisted as the controls. All participants were evaluated by detailed medical history, physical examination, an electrocardiogram and echocardiography. Cardiac catheterization, angiography, a chest X-ray and cardiac magnetic resonance imaging were performed only if there was a strong clinical indication. Medical records were also reviewed in the case of deceased or unavailable relatives. The diagnosis and classification of AF was made in accordance with the guidelines for the management of patients with AF $(1,88)$. Briefly, AF was diagnosed by a standard 12-lead electrocardiogram demonstrating no P-waves and irregular R-R intervals regardless of clinical symptoms. Lone AF was defined as AF occurring in individuals $<60$ years of age without other cardiac or systemic diseases by physical examination, electrocardiogram, transthoracic echocardiogram and extensive laboratory tests. Familial AF was termed when lone AF existed in an additional 2 or more first- or second-degree relatives. Relatives with AF occurring at any age in the presence of structural heart disease (hypertensive, ischemic, myocardial or valvular) were classified as 'undetermined' for having an inherited form of AF. The 'undetermined' classification was also used if documentation of AF on an electrocardiogram tracing was lacking in relatives with symptoms consistent with AF (palpitation, dyspnea and light-headedness), or if a screening electrocardiogram and echocardiogram were not performed, irrespective of the symptoms. Relatives were classified as 'unaffected' if they were asymptomatic and had a normal electrocardiogram. Paroxysmal AF was defined as AF lasting $>30 \mathrm{sec}$ that terminated spontaneously. Persistent AF was defined as AF lasting $>1$ week and requiring either pharmacological therapy or electrical cardioversion for termination. AF that was refractory to cardioversion or that was allowed to continue was classified as permanent AF. Peripheral venous blood samples were obtained from all the participants. The clinical studies were performed with investigators blinded to the results of the genotypes. This study conformed to the principles of the Declaration of Helsinki and the study protocol was approved by the local Institutional Ethics Committee of Shanghai Chest Hospital, Shanghai Jiao Tong University (the ethical approval number for cases and controls: KS1101; the date of the approval: April 12, 2011). Written informed consent was obtained from all participants prior to enrollment.

Genetic scanning of NKX2-6. Genomic DNA was extracted from the blood lymphocytes of each participant using the Wizard Genomic DNA Purification kit (Promega, Madison, WI, USA). The coding exons and exon-intron boundaries of the $N K X 2-6$ gene were sequenced in the 150 unrelated patients with lone AF. The available relatives of the index patient harboring an identified NKX2-6 mutation and the 200 unrelated control individuals were genotyped for $N K X 2-6$. The referential genomic DNA sequence of $N K X 2-6$ was derived 
Table I. The intronic primers used to amplify the coding exons and exon-intron boundaries of NKX2-6.

\begin{tabular}{llll}
\hline Exon & Forward primer & Reverse primer & Amplicon \\
\hline 1 & 5'-GAC AAG ACG GGA AGT TCA GG-3' & 5'-TCG AAC CCA GGA GAT AGG AG-3' & 447 bp \\
2-a & 5'-CCA GGG AGA GGA AAG TCT TG-3' & 5'-CAG GAC GGG CAC AGC TAC TC-3' & 454 bp \\
2-b & 5'-AGA ACC GAC GCT ACA AAT GC-3' & 5'-GAG ATC CCT CCG GAAAGA AG-3' & 500 bp \\
\hline
\end{tabular}

NKX2-6, NK2 homeobox 6; bp, base pairs.

from GenBank (accession no. NG_030636), a gene sequence database at the National Center for Biotechnical Information (NCBI; http://www.ncbi.nlm.nih.gov/). With the help of online Primer 3 software (http://frodo.wi.mit.edu/), the primer pairs used to amplify the coding regions and flanking splice junction sites of $N K X 2-6$ by polymerase chain reaction (PCR) were designed as described in Table I. PCR was carried out using HotStar TaqDNA Polymerase (Qiagen, Hilden, Germany) on a Veriti Thermal Cycler (Applied Biosystems, Foster City, CA, USA) with standard conditions and concentrations of reagents. Amplified products were purified with the QIAquick Gel Extraction kit (Qiagen). Both strands of each amplicon were sequenced using the BigDye ${ }^{\circledR}$ Terminator v3.1 Cycle Sequencing kit under an ABI PRISM 3130 XL DNA Analyzer (both from Applied Biosystems). The sequencing primers were the same as those mentioned above for the specific region amplifications. DNA sequences were viewed and analyzed using DNA Sequencing Analysis Software v5.1 (Applied Biosystems). The variant was validated by re-sequencing of an independent PCR-generated amplicon from the same subject. In addition, for an identified sequence variant, the single nucleotide polymorphism (SNP; http://www.ncbi.nlm.nih.gov/ SNP) and human gene mutation (HGM; http://www.hgmd.org) databases were queried to confirm its novelty.

Alignment of multiple NKX2-6 protein sequences. The conservation of the amino acid altered by missense mutation was appraised by aligning human NKX2-6 to chimpanzee, monkey, dog, cattle, mouse, rat, fowl, zebrafish and frog NKX2-6 using the HomoloGene and Show Multiple Alignment links on the NCBI website (http://www.ncbi.nlm.nih.gov/homologene).

Prediction of the causative potential of an NKX2-6 sequence variation. The disease-causing potential of an NKX2-6 sequence variation was predicted using an online program, MutationTaster (http://www.mutationtaster.org), automatically yielding a probability for a variation to be either a pathogenic mutation or a benign polymorphism. Notably, the P-value used here is the probability of the correct prediction rather than the probability of error as used in t-test statistics (i.e., a value close to 1 indicates a high accuracy of the prediction). Additionally, another online program PolyPhen-2 (http://genetics.bwh. harvard.edu/pph2) was also used to evaluate the pathogenic likeliness of an amino acid substitution.

Expression plasmids and site-directed mutagenesis. The recombinant expression vector NKX2-5-pEFSA and the ANF-luciferase (ANF-luc) reporter plasmid, which contains the 2,600 bp 5'-flanking region of the ANF gene, were kindly provided by Dr. Ichiro Shiojima from Chiba University School of Medicine, Chiba, Japan. Owing to unknown downstream genes of NKX2-6, NKX2-5 was used as a surrogate in transcriptional analysis to assess the functional consequences of the Q175H homeodomain substitution (104). Alignment between the human NKX2-6 and NKX2-5 proteins illustrated that Q175H-mutant NKX2-6 was equivalent to Q181H-mutant NKX2-5 (data not shown). The c. $543 \mathrm{G}>\mathrm{C}$ transition, which was predicted to generate the p.Q181H mutation, was introduced into wild-type NKX2-5 using a QuickChange II XL Site-Directed Mutagenesis kit (Stratagene, La Jolla, CA, USA) with a complementary pair of primers. The mutant was sequenced to confirm the desired mutation and to exclude any other sequence variations.

Reporter gene assays. COS-7 cells from our cell bank were cultured in Dulbecco's modified Eagle's medium supplemented with $10 \%$ fetal calf serum. The internal control reporter plasmid pGL4.75 (hRluc/CMV, Promega) was used in transient transfection analyses to evaluate the transcriptional activity of the NKX2-5 mutant. The COS-7 cells were transfected with $0.4 \mu \mathrm{g}$ of wild-type or mutant NKX2-5-pEFSA, $1.0 \mu \mathrm{g}$ of ANF-luc and $0.04 \mu \mathrm{g}$ of pGL4.75 using PolyFect Transfection Reagent (Qiagen). For co-transfection experiments, $0.2 \mu \mathrm{g}$ of wild-type NKX2-5-pEFSA, $0.2 \mu \mathrm{g}$ of mutant NKX2-5-pEFSA, $1.0 \mu \mathrm{g}$ of ANF-luc and $0.04 \mu \mathrm{g}$ of pGL4.75 were used. Firefly luciferase and Renilla luciferase activities were measured using the Dual-Glo luciferase assay system (Promega) $48 \mathrm{~h}$ after transfection. The activity of the $A N F$ promoter was presented as the fold activation of firefly luciferase relative to Renilla luciferase. Three independent experiments were performed at minimum for wild-type and mutant $N K X 2-5$.

Statistical analysis. Data are expressed as the means \pm SD. Continuous variables were tested for normality of distribution and the Student's unpaired t-test was used for the comparison of numeric variables between 2 groups. Comparison of the categorical variables between 2 groups was performed using Pearson's $\chi^{2}$ test or Fisher's exact test where appropriate. A two-tailed P-value of $<0.05$ was considered to indicate a statistical difference.

\section{Results}

Clinical characteristics of the study subjects. A total of 150 unrelated patients with lone AF were clinically evaluated in contrast to 200 control individuals. None of them had underlying comorbidities or traditional risk factors for AF. There was 


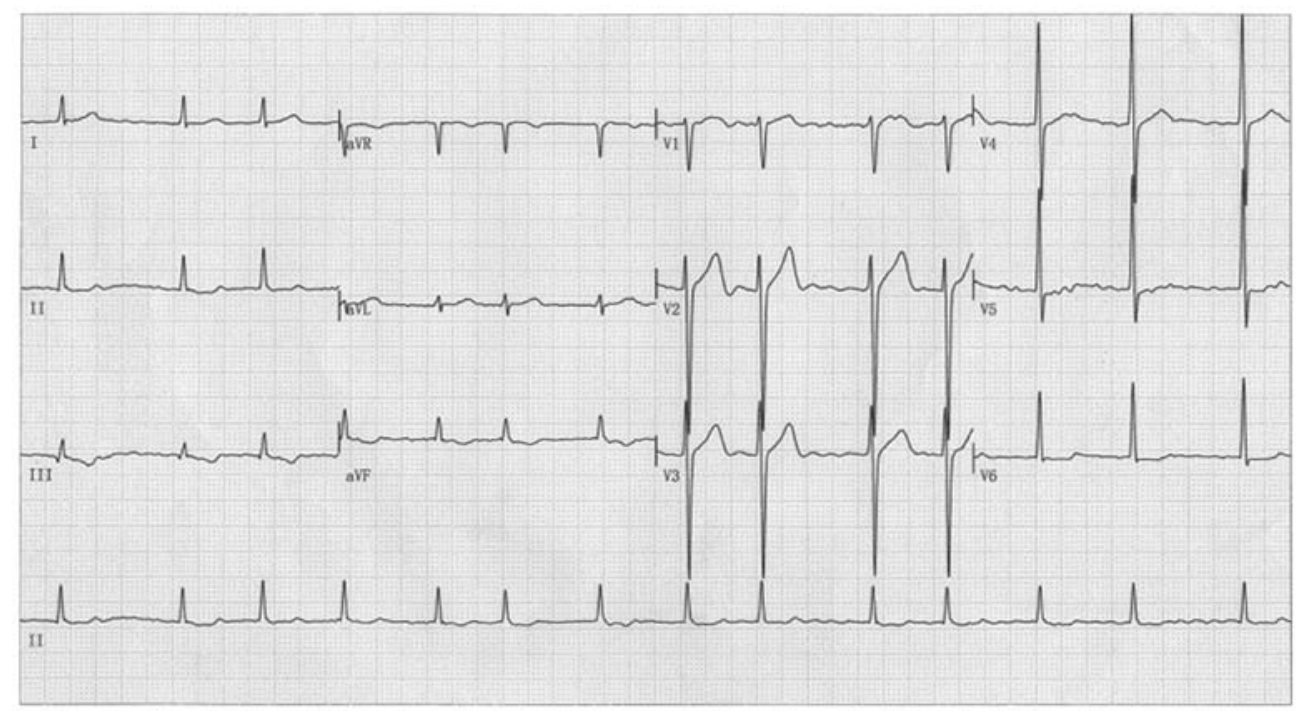

Figure 1. Standard 12-lead surface electrocardiogram of the proband from family 1 . The electrocardiogram shows atrial fibrillation.

Table II. The baseline clinical characteristics of the 150 patients with lone atrial fibrillation.

\begin{tabular}{ll}
\hline Variables & Statistics
\end{tabular}

Baseline demographics

Age at first diagnosis of atrial

$51.4 \pm 10.2$

fibrillation (years)

Male (n, \%)

Body mass index $\left(\mathrm{kg} / \mathrm{m}^{2}\right)$

Left ventricular ejection fraction (\%)

$23.4 \pm 3.8$

$64.2 \pm 6.1$

Left atrial diameter ( $\mathrm{mm})$

$37.0 \pm 4.5$

Personal history of atrial fibrillation (n, \%)

Type of atrial fibrillation at presentation

Paroxysmal

Persistent

$36(24.0)$

Permanent

History of cardioversion

$113(75.3)$

Positive family history of atrial fibrillation

Medical history (n, \%)

History of syncope

History of pacemaker)

Thromboembolic complication

Medications (n, \%)

$\begin{array}{lr}\text { Amiodarone } & 105(70.0) \\ \text { Warfarin } & 91(60.7) \\ \text { Aspirin } & 30(20.0) \\ \text { Digitalis } & 22(14.7) \\ \beta \text {-acceptor blocker } & 13(8.7) \\ \text { Calcium channel blocker } & 9(6.0)\end{array}$

Continuous variables are expressed as the means \pm standard deviation

no significant difference between the patient and control groups in baseline characteristics including age, gender, body mass index, blood pressure, fasting blood glucose, serum lipid levels, left atrial dimension, left ventricular ejection fraction, heart rate at rest, as well as lifestyle (data not shown). The baseline clinical characteristics of the study subjects are summarized in Table II.

NKX2-6 mutation. By direct sequencing of the NKX2-6 gene in the 150 unrelated patients with lone AF, a heterozygous mutation was identified in 1 patient, with a mutational prevalence of approximately $0.67 \%$. Specifically, a substitution of cytosine for guanine in the third nucleotide of codon 175 (c.525G $>C$ ), predicting the transition of glutamine into histidine at amino acid position 175 (p.Q175H) was identified in the index patient from family 1. A representative 12-lead electrocardiogram of the proband with AF is shown in Fig. 1. The sequence chromatograms showing the detected heterozygous NKX2-6 mutation of c. $525 \mathrm{G}>\mathrm{C}$ compared with its control sequence are shown in Fig. 2. The schematic diagrams of NKX2-6 and NKX2-5 proteins showing the structural domains and location of the mutation identified in this study are presented in Fig. 3. The missense mutation was neither observed in the control population nor reported in the single nucleotide polymorphism (SNP) and HGM databases. Genetic screening of the family of the proband revealed that the mutation was present in all affected living family members, but absent in the unaffected family members examined. Analysis of the pedigree demonstrated that the mutation co-segregated with AF transmitted in an autosomal dominant pattern and with complete penetrance. The pedigree structure of the family is illustrated in Fig. 4. The phenotypic characteristics and status of the NKX2-6 mutation of the affected family members are listed in Table III.

Multiple alignments of NKX2-6 protein sequences. As shown in Fig. 5, a cross-species alignment of NKX2-6 protein sequences revealed that the altered amino acid p.Q175H was completely conserved evolutionarily, suggesting its functional importance.

Disease-causing potential of the NKX2-6 variation. The sequence variation of c.525G $>$ C detected in the NKX2-6 gene 


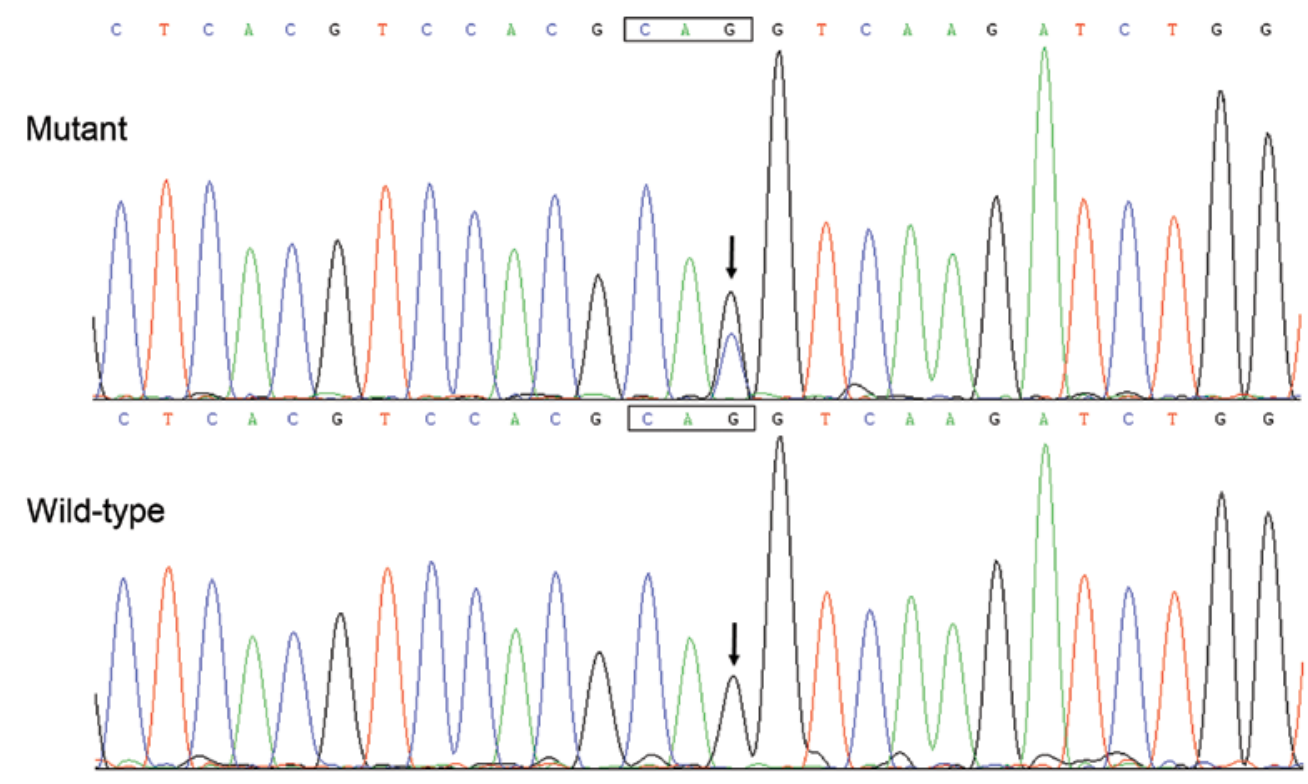

Figure 2. Sequence electropherograms showing the NKX2-6 variation compared with its control. The arrow indicates the heterozygous nucleotides of G/C in the proband from family 1 (mutant) or the homozygous nucleotides of G/G in the corresponding control individual (wild-type). The rectangle denotes the nucleotides comprising a codon of NKX2-6.

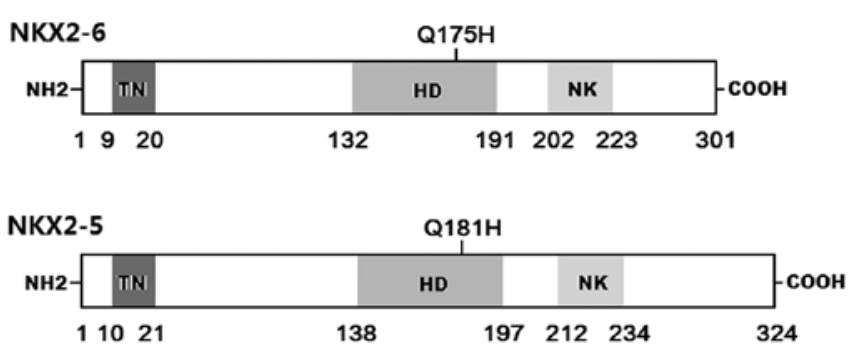

Figure 3. Schematic diagrams of NKX2-6 and NKX2-5 protein structures with the identified mutation indicated. The mutation identified in patients with familial atrial fibrillation is shown above the structural domains. NH2, amino-terminus; TN, tinman domain; HD, homeodomain; NK, nucleotide kinase domain; $\mathrm{COOH}$, carboxyl-terminus.

was predicted by MutationTaster to be a disease-causing mutation with a P-value of 0.998 . No SNPs in the altered region were reported in the MutationTaster database. Accordingly, the amino acid substitution of Q175H in NKX2-6 was also predicted by PolyPhen-2 to be possibly damaging, with a score of 1.000 (sensitivity, 0.00 ; specificity, 1.00).

Reduced transcriptional activity of Q181H-mutant NKX2-5. Due to unknown target genes of NKX2-6, Q181H-mutant NKX2-5 was used as a surrogate to assess the functional sequelae of Q175H-mutant NKX2-6. As shown in Fig. 6, the same amount $(0.4 \mu \mathrm{g})$ of wild-type and mutant $N K X 2-5$ activated the ANF-luciferase $(A N F)$ promoter by approximately 11- and 4-fold, respectively. When the same amount of wildtype NKX2-5 $(0.2 \mu \mathrm{g})$ was co-transfected with mutant NKX2-5 $(0.2 \mu \mathrm{g})$, the induced activation of the ANF promoter was approximately 6-fold. These results demonstrate that Q181Hmutant NKX2-5 is associated with a significantly diminished transcriptional activity compared with its wild-type counterpart, suggesting that the homeobox substitution Q175H results in functional defects of NKX2-5

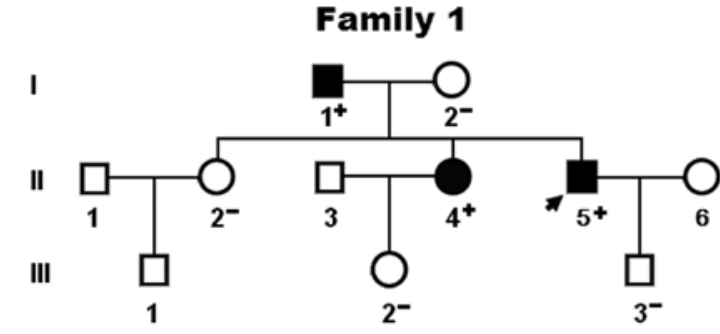

Figure 4. Pedigree structure of the family with atrial fibrillation. Family members are identified by generations and numbers. Square, male family member; circle, female member; closed symbol, affected member; open symbol, unaffected member; arrow, proband; +, carrier of the heterozygous missense mutation; -, non-carrier.

\section{Discussion}

In this study, a novel heterozygous mutation of p.Q175H in the NKX2-6 gene was identified in a family with familial AF. The missense mutation co-segregated with AF in the family and was absent in the 400 reference chromosomes from an ethnically-matched control population. A cross-species alignment of multiple NKX2-6 protein sequences revealed that the altered amino acid was completely conserved evolutionarily. Functional analyses in vitro and in silico indicated that the homeobox substitution resulted in functional impairment. Therefore, it is highly likely that mutant NKX2-6 predisposes these mutation carriers to AF.

NKX2-6 is a vertebrate homolog of Drosophila homeoboxcontaining protein termed 'tinman'. It is expressed in early embryonic heart progenitor cells, playing an important role in proper cardiovascular development (102-105). The human NKX2-6 gene maps to chromosome 8p21.2 and consists of 2 exons encoding a protein of 301 amino acids (104). The NKX2-6 protein contains an evolutionarily conserved homeodomain that recognizes and binds to a consensus DNA motif, 
Table III. Phenotypic characteristics and status of NKX2-6 mutation in the affected pedigree members.

\begin{tabular}{|c|c|c|c|c|c|c|c|c|c|c|}
\hline \multicolumn{4}{|c|}{ Subject information } & \multirow{2}{*}{$\frac{\text { Phenotype }}{\mathrm{AF}}$} & \multicolumn{3}{|c|}{ Electrocardiogram } & \multicolumn{2}{|c|}{ Echocardiogram } & \multirow{2}{*}{$\begin{array}{l}\text { Genotype } \\
\text { NKX2-6 } \\
\text { mutation }\end{array}$} \\
\hline Identity & Gender & $\begin{array}{c}\text { Age at } \\
\text { time of } \\
\text { study (years) }\end{array}$ & $\begin{array}{c}\text { Age at } \\
\text { diagnosis of } \\
\text { AF (years) }\end{array}$ & & $\begin{array}{l}\text { Heart rate } \\
\text { (beats/min) }\end{array}$ & $\begin{array}{c}\text { QRS } \\
\text { interval } \\
\text { (msec) }\end{array}$ & QTc & $\begin{array}{l}\text { LAD } \\
(\mathrm{mm})\end{array}$ & $\begin{array}{l}\text { LVEF } \\
(\%)\end{array}$ & \\
\hline Family 1 & & & & & & & & & & Q175H \\
\hline $\mathrm{I}-1$ & M & 65 & 40 & Permanent & 87 & 84 & 425 & 40 & 65 & $+/-$ \\
\hline II-4 & $\mathrm{F}$ & 40 & 35 & Persistent & 82 & 86 & 498 & 35 & 60 & $+/-$ \\
\hline II-5 & M & 38 & 37 & Paroxysmal & 84 & 90 & 437 & 38 & 67 & $+/-$ \\
\hline
\end{tabular}

AF, atrial fibrillation; F, female; M, male; QTc, corrected QT interval; LAD, left atrial dimension; LVEF, left ventricular ejection fraction; + , present; -, absent.

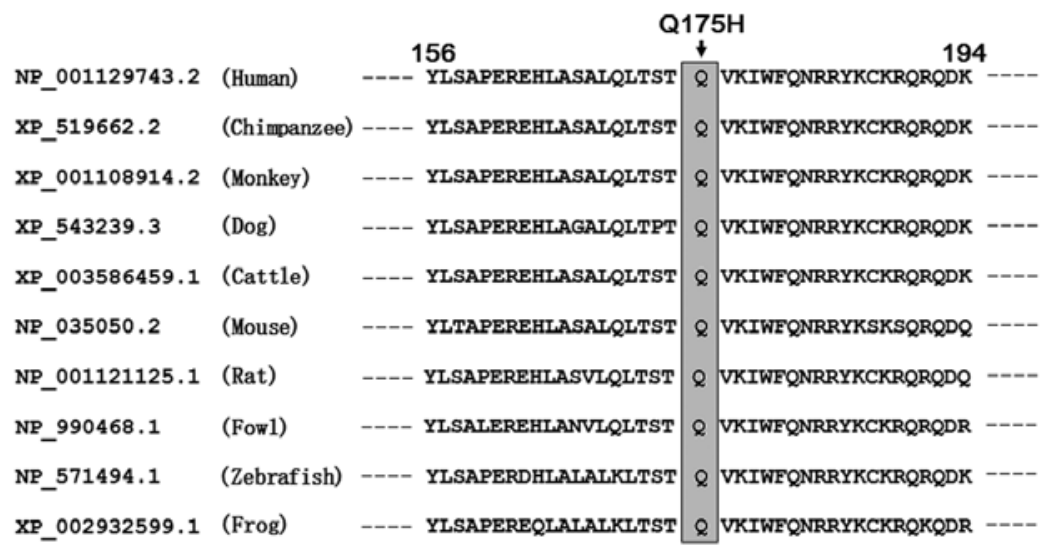

Figure 5. Multiple alignments of NKX2-6 protein sequences among species. The altered amino acid of p.Q175H is completely conserved evolutionarily across species.

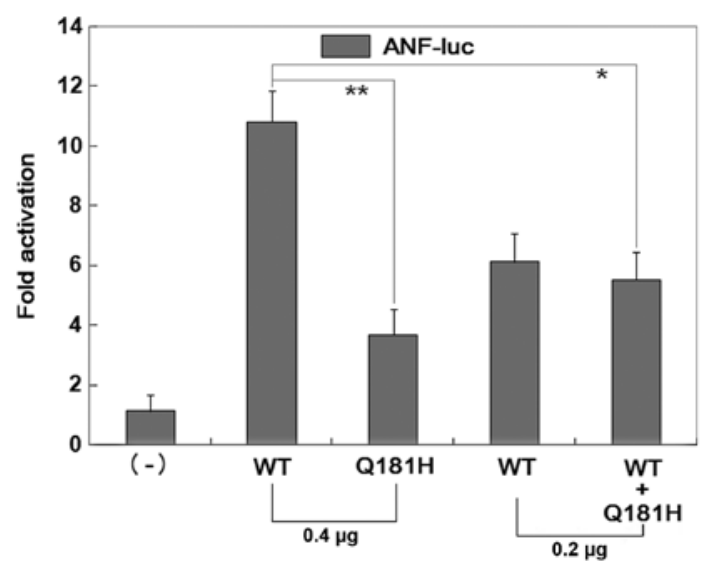

Figure 6. Q181H-mutant NKX2-5 shows impaired transcriptional activation. Activation of atrial natriuretic factor promoter driven luciferase reporter in COS-7 cells by wild-type (WT) or Q181H-mutant NKX2-5, alone or together, showed significantly reduced transcriptional activation by the mutant protein. Experiments were performed in triplicate, and mean and standard deviations are shown. ${ }^{* *} \mathrm{P}<0.001$ and ${ }^{*} \mathrm{P}<0.005$, respectively, when compared with wild-type NKX2-5. WT, wild-type.

AAGTG. The homeodomain is centrally located at amino acid positions 132-191 and is predominantly involved in target
DNA binding, nuclear translocation, as well as interaction with other transcription factors $(104,106)$. The NKX2-6 mutation of p.Q175H identified in this study is located in the homeodomain, and thus may exert influence on the transcriptional activity of NKX2-6 by interfering with its nuclear distribution or DNA-binding ability.

In order to assess the functional characteristics of the Q175H homeodomain substitution in NKX2-6, NKX2-5 was selected as a surrogate based on the following reasons: firstly, no downstream genes or a binding site recognition sequence for NKX2-6 have been substantiated. Secondly, NKX2-5 and NKX2-6 are 2 members of the NK2 family of transcription factors, and they share a highly conserved structural motif, particularly for the homeodomain. Thirdly, biochemical assays of NKX2-5 have been well characterized. Finally, there are in vivo studies corroborating that NKX2-5 may compensate for the lack of NKX2-6 during embryogenesis, therefore suggesting that some DNA binding and transcriptional regulatory activities are shared (102-104). Consequently, functional analysis of Q181H-mutant NKX2-5 instead of Q175H NKX2-6 revealed that the homeodomain substitution significantly diminished transcriptional activity on a target gene, $A N F$. These findings suggest that the haploinsufficiency or dominantnegative effects caused by the NKX2-6 mutation are potentially 
alternative molecular pathological mechanisms responsible for the development of AF.

The findings that genetically compromised $N K X 2-6$ enhances the vulnerability to AF may be partially attributed to the abnormal cardiovascular development (65). During murine embryogenesis, NKX2-6 is expressed at opposite poles of the developing heart: from E8-8.5 in posterior myocardial progenitors, then the sinus venosa and dorsal pericardium, and from E9.5 in the outflow tract myocardium (102). Although the targeted disruption of $N K X 2-6$ has been shown to result in normal mouse embryos with no obvious heart malformations, $N K X 2-5$ mRNA expression expanded to the regions of $N K X 2-6$, indicative of functional compensation for loss of $N K X 2-6$ in these embryos. Furthermore, overlapping functions for $N K X 2-6$ and $N K X 2-5$ had been verified in double knockout mouse embryos, in which the development of the atria was less advanced, indicating that these 2 genes are essential for cardiac development (103). Given the high degree of homology between NKX2-6 and NKX2-5 over the homeodomain (90\% identity) and overlapping cardiac expression patterns, these data suggest the possibility that NKX2-6 and NKX2-5 synergistically regulate some target genes (104). In humans, mutations in both NKX2-5 and NKX2-6 have been associated with various congenital cardiovascular defects $(66-68,104,105)$, and moreover, multiple NKX2-5 mutations have been causally implicated in AF (88-90), which suggest that mutant NKX2-6 may presumably contribute to the development of AF through a similar transcriptional mechanism.

In conclusion, to the best of our knowledge, the present study associates mutant NKX2-6 with enhanced susceptibility to AF for the first time, providing novel insight into the molecular pathogenesis of AF and suggesting potential strategies for the antenatal prophylaxis and personalized treatment of AF.

\section{Acknowledgements}

The authors are really thankful to the participants for their participation in the study. This study was supported in part by grants from the Key Discipline Development Program of Health Bureau of Jian-An district, Shanghai, China (JWXK201201), the National Natural Science Fund of China (81270161, 81370301 and 81070153) and the Natural Science Fund of Shanghai, China (13ZR1438400).

\section{References}

1. Fuster V, Rydén LE, Cannom DS, Crijns HJ, Curtis AB Ellenbogen KA, Halperin JL, Kay GN, Le Huezey JY, Lowe JE, Olsson SB, Prystowsky EN, Tamargo JL, Wann LS, Smith SC Jr, Priori SG, Estes NA III, Ezekowitz MD, Jackman WM, January CT, Lowe JE, Page RL, Slotwiner DJ, Stevenson WG, Tracy CM, Jacobs AK, Anderson JL, Albert N, Buller CE, Creager MA, Ettinger SM, Guyton RA, Halperin JL, Hochman JS, Kushner FG, Ohman EM, Stevenson WG, Tarkington LG and Yancy CW; American College of Cardiology Foundation/American Heart Association Task Force: 2011 ACCF/AHA/HRS focused updates incorporated into the ACC/AHA/ESC 2006 guidelines for the management of patients with atrial fibrillation: a report of the American College of Cardiology Foundation/American Heart Association Task Force on practice guidelines. Circulation 123: e269-e367, 2011.

2. Go AS, Hylek EM, Phillips KA, Chang Y, Henault LE, Selby JV and Singer DE: Prevalence of diagnosed atrial fibrillation in adults: national implications for rhythm management and stroke prevention: the AnTicoagulation and Risk Factors in Atrial Fibrillation (ATRIA) Study. JAMA 285: 2370-2375, 2001.
3. Lloyd-Jones DM, Wang TJ, Leip EP, Larson MG, Levy D, Vasan RS, D'Agostino RB, Massaro JM, Beiser A, Wolf PA and Benjamin EJ: Lifetime risk for development of atrial fibrillation: the Framingham Heart Study. Circulation 110: 1042-1046, 2004.

4. Miyasaka Y, Barnes ME, Gersh BJ, Cha SS, Bailey KR, Abhayaratna WP, Seward JB and Tsang TS: Secular trends in incidence of atrial fibrillation in Olmsted County, Minnesota, 1980 to 2000 , and implications on the projections for future prevalence. Circulation 114: 119-125, 2006.

5. Benjamin EJ, Wolf PA, D'Agostino RB, Silbershatz H, Kannel WB and Levy D: Impact of atrial fibrillation on the risk of death: the Framingham Heart Study. Circulation 98: 946-952, 1998.

6. Wolf PA, Abbott RD and Kannel WB: Atrial fibrillation as an independent risk factor for stroke: the Framingham Study. Stroke 22: 983-988, 1991.

7. Singh SN, Tang XC, Singh BN, Dorian P, Reda DJ, Harris CL, Fletcher RD, Sharma SC, Atwood JE, Jacobson AK, Lewis HD Jr, Lopez B, Raisch DW and Ezekowitz MD; SAFE-T Investigators: Quality of life and exercise performance in patients in sinus rhythm versus persistent atrial fibrillation: a Veterans Affairs Cooperative Studies Program Substudy. J Am Coll Cardiol 48: 721-730, 2006.

8. Santangeli P, Di Biase L, Bai R, Mohanty S, Pump A, Cereceda Brantes M, Horton R, Burkhardt JD, Lakkireddy D, Reddy YM, Casella M, Dello Russo A, Tondo C and Natale A: Atrial fibrillation and the risk of incident dementia: a metaanalysis. Heart Rhythm 9: 1761-1768, 2012.

9. Chao TF, Tsao HM, Ambrose K, Lin YJ, Lin WS, Chang SL, Lo LW, Hu YF, Tuan TC, Suenari K, Li CH, Hartono B, Chang HY, Chung FP, Hanafy DA, Lin WY and Chen SA: Renal dysfunction and the risk of thromboembolic events in patients with atrial fibrillation after catheter ablation - the potential role beyond the CHA2DS2-VASc score. Heart Rhythm 9: 1755-1760, 2012.

10. Calvo N, Bisbal F, Guiu E, Ramos P, Nadal M, Tolosana JM, Arbelo E, Berruezo A, Sitges M, Brugada J and Mont L: Impact of atrial fibrillation-induced tachycardiomyopathy in patients undergoing pulmonary vein isolation. Int J Cardiol 168: 4093-4097, 2013.

11. Naji F, Pagliaruzzi M, Penko M, Kanic V and Vokac D: Changes in left ventricular filling in patients with persistent atrial fibrilation. Int J Med Sci 10: 1876-1879, 2013.

12. Tayebjee MH, Gilbert K, Macdonald W, Hogarth AJ, Lewis NT and Tan LB: Atrial fibrillation reduces the functional REServe of the heart by a fifth: a pilot FRESH-AF study. Int J Cardiol 168: 4369-4370, 2013

13. Weijs B, Pisters R, Haest RJ, Kragten JA, Joosen IA, Versteylen M, Timmermans CC, Pison L, Blaauw Y, Hofstra L, Nieuwlaat R, Wildberger J and Crijns HJ: Patients originally diagnosed with idiopathic atrial fibrillation more often suffer from insidious coronary artery disease compared to healthy sinus rhythm controls. Heart Rhythm 9: 1923-1929, 2012.

14. Soliman EZ, Safford MM, Muntner P, Khodneva Y, Dawood FZ, Zakai NA, Thacker EL, Judd S, Howard VJ, Howard G, Herrington DM and Cushman M: Atrial fibrillation and the risk of myocardial infarction. JAMA Intern Med 174: 107-114, 2014.

15. Marijon E, Le Heuzey JY, Connolly S, Yang S, Pogue J, Brueckmann M, Eikelboom J, Themeles E, Ezekowitz M, Wallentin L and Yusuf S; RE-LY Investigators: Causes of death and influencing factors in patients with atrial fibrillation: a competingrisk analysis from the randomized evaluation of long-term anticoagulant therapy study. Circulation 128: 2192-2201, 2013.

16. Go AS, Mozaffarian D, Roger VL, Benjamin EJ, Berry JD, Blaha MJ, DaiS, Ford ES, Fox CS, Franco S, Fullerton HJ, Gillespie C, Hailpern SM, Heit JA, Howard VJ, Huffman MD, Judd SE, Kissela BM, Kittner SJ, Lackland DT, Lichtman JH, Lisabeth LD, Mackey RH, Magid DJ, Marcus GM, Marelli A, Matchar DB, McGuire DK, Mohler ER III, Moy CS, Mussolino ME, Neumar RW, Nichol G, Pandey DK, Paynter NP, Reeves MJ, Sorlie PD, Stein J, Towfighi A, Turan TN, Virani SS, Wong ND, Woo D and Turner MB; American Heart Association Statistics Committee and Stroke Statistics Subcommittee: Heart disease and stroke statistics - 2014 update: a report from the American Heart Association. Circulation 129: e28-e292, 2014.

17. Ball J, Carrington MJ, McMurray JJ and Stewart S: Atrial fibrilation: profile and burden of an evolving epidemic in the 21st century. Int J Cardiol 67: 1807-1824, 2013.

18. Coyne KS, Paramore C, Grandy S, Mercader M, Reynolds M and Zimetbaum P: Assessing the direct costs of treating nonvalvular atrial fibrillation in the United States. Value Health 9: 348-356, 2006. 
19. Nattel S: New ideas about atrial fibrillation 50 years on. Nature 415: 219-226, 2002.

20. Abed HS, Samuel CS, Lau DH, Kelly DJ, Royce SG, Alasady M, Mahajan R, Kuklik P, Zhang Y, Brooks AG, Nelson AJ, Worthley SG, Abhayaratna WP, Kalman JM, Wittert GA and Sanders P: Obesity results in progressive atrial structural and electrical remodeling: implications for atrial fibrillation. Heart Rhythm 10: 90-100, 2013.

21. Naruse $Y$, Tada $H$, Satoh $M$, Yanagihara $M$, Tsuneoka $H$, Hirata Y, Ito Y, Kuroki K, Machino T, Yamasaki H, Igarashi M, Sekiguchi Y, Sato A and Aonuma K: Concomitant obstructive sleep apnea increases the recurrence of atrial fibrillation following radiofrequency catheter ablation of atrial fibrillation: clinical impact of continuous positive airway pressure therapy. Heart Rhythm 10: 331-337, 2013.

22. Chao TF, Hung CL, Chen SJ, Wang KL, Chen TJ, Lin YJ, Chang SL, Lo LW, Hu YF, Tuan TC and Chen SA: The association between hyperuricemia, left atrial size and new-onset atrial fibrillation. Int J Cardiol 168: 4027-4032, 2013.

23. Andrade J, Khairy P, Dobrev D and Nattel S: The clinical profile and pathophysiology of atrial fibrillation: relationships among clinical features, epidemiology, and mechanisms. Circ Res 114 1453-1468, 2014.

24. Fox CS, Parise H, D'Agostino RB Sr, Lloyd-Jones DM, Vasan RS, Wang TJ, Levy D, Wolf P and Benjamin EJ: Parental atrial fibrillation as a risk factor for atrial fibrillation in offspring. JAMA 291: 2851-2855, 2004

25. Ellinor PT, Yoerger DM, Ruskin JN and MacRae CA: Familial aggregation in lone atrial fibrillation. Hum Genet 118: 179-184, 2005.

26. Arnar DO, Thorvaldsson S, Manolio TA, Thorgeirsson G, Kristjansson K, Hakonarson $\mathrm{H}$ and Stefansson K: Familial aggregation of atrial fibrillation in Iceland. Eur Heart J 27: 708-712, 2006

27. Christophersen IE, Ravn LS, Budtz-Joergensen E, Skytthe A, Haunsoe S, Svendsen JH and Christensen K: Familial aggregation of atrial fibrillation: a study in Danish twins. Circ Arrhythm Electrophysiol 2: 378-383, 2009.

28. Yang YQ, Zhang XL, Wang XH, Tan HW, Shi HF, Fang WY and Liu X: Familial aggregation of lone atrial fibrillation in Chinese population. Intern Med 49: 2385-2391, 2010.

29. Lubitz SA, Yin X, Fontes JD, Magnani JW, Rienstra M, Pai M, Villalon ML, Vasan RS, Pencina MJ, Levy D, Larson MG, Ellinor PT and Benjamin EJ: Association between familial atrial fibrillation and risk of new-onset atrial fibrillation. JAMA 304 2263-2269, 2010.

30. Zöller B, Ohlsson H, Sundquist J and Sundquist K: High familial risk of atrial fibrillation/atrial flutter in multiplex families: a nationwide family study in Sweden. J Am Heart Assoc 2: e003384, 2012

31. Oyen N, Ranthe MF, Carstensen L, Boyd HA, Olesen MS, Olesen SP, Wohlfahrt J and Melbye M: Familial aggregation of lone atrial fibrillation in young persons. J Am Coll Cardiol 60: 917-921, 2012.

32. Brugada R, Tapscott T, Czernuszewicz GZ, Marian AJ, Iglesias A, Mont L, Brugada J, Girona J, Domingo A, Bachinski LL and Roberts R: Identification of a genetic locus for familial atrial fibrillation. N Engl J Med 336: 905-911, 1997.

33. Chen YH, Xu SJ, Bendahhou S, Wang XL, Wang Y, Xu WY, Jin HW, Sun H, Su XY, Zhuang QN, Yang YQ, Li YB, Liu Y, Xu HJ, Li XF, Ma N, Mou CP, Chen Z, Barhanin J and Huang W: KCNQ1 gain-of-function mutation in familial atrial fibrillation. Science 299: 251-254, 2003.

34. Ellinor PT, Shin JT, Moore RK, Yoerger DM and MacRae CA: Locus for atrial fibrillation maps to chromosome 6q14-16. Circulation 107: 2880-2883, 2003.

35. Oberti C, Wang L, Li L, Dong J, Rao S, Du W and Wang Q: Genome-wide linkage scan identifies a novel genetic locus on chromosome $5 \mathrm{p} 13$ for neonatal atrial fibrillation associated with sudden death and variable cardiomyopathy. Circulation 110 3753-3759, 2004

36. Volders PG, Zhu Q, Timmermans C, Eurlings PM, Su X, Arens YH, Li L, Jongbloed RJ, Xia M, Rodriguez LM and Chen YH: Mapping a novel locus for familial atrial fibrillation on chromosome 10p11-q21. Heart Rhythm 4: 469-475, 2007.

37. Darbar D, Hardy A, Haines JL and Roden DM: Prolonged signal-averaged $\mathrm{P}$-wave duration as an intermediate phenotype for familial atrial fibrillation. J Am Coll Cardiol 51: 1083-1089, 2008 .
38. Olesen MS, Bentzen BH, Nielsen JB, Steffensen AB, David JP, Jabbari J, Jensen HK, Hauns $\emptyset$ S, Svendsen JH and Schmitt N: Mutations in the potassium channel subunit KCNE1 are associated with early-onset familial atrial fibrillation. BMC Med Genet 13: 24, 2012.

39. Yang Y, Xia M, Jin Q, Bendahhou S, Shi J, Chen Y, Liang B, Lin J, Liu Y, Liu B, Zhou Q, Zhang D, Wang R, Ma N, Su X, Niu K, Pei Y, Xu W, Chen Z, Wan H, Cui J, Barhanin J and Chen Y: Identification of a KCNE2 gain-of-function mutation in patients with familial atrial fibrillation. Am J Hum Genet 75: 899-905, 2004

40. Nielsen JB, Bentzen BH, Olesen MS, David JP, Olesen SP, Hauns $\varnothing$ S, Svendsen JH and Schmitt N: Gain-of-function mutations in potassium channel subunit KCNE2 associated with early-onset lone atrial fibrillation. Biomark Med 8: 557-570, 2014.

41. Lundby A, Ravn LS, Svendsen JH, Hauns S, Olesen SP and Schmitt N: KCNE3 mutation V17M identified in a patient with lone atrial fibrillation. Cell Physiol Biochem 21: 47-54, 2008.

42. Zeng Z, Tan C, Teng S, Chen J, Su S, Zhou X, Wang F, Zhang S, $\mathrm{Gu} \mathrm{D}$, Makielski JC and $\mathrm{Pu}$ J: The single nucleotide polymorphisms of $\mathrm{I}(\mathrm{Ks})$ potassium channel genes and their association with atrial fibrillation in a Chinese population. Cardiology 108: 97-103, 2007.

43. Ravn LS, Aizawa Y, Pollevick GD, Hofman-Bang J, Cordeiro JM, Dixen U, Jensen G, Wu Y,Burashnikov E, Haunso S, Guerchicoff A, Hu D, Svendsen JH, Christiansen M and Antzelevitch C: Gain of function in IKs secondary to a mutation in KCNE5 associated with atrial fibrillation. Heart Rhythm 5: 427-435, 2008

44. Hong K, Bjerregaard P, Gussak I and Brugada R: Short QT syndrome and atrial fibrillation caused by mutation in $\mathrm{KCNH} 2 . \mathrm{J}$ Cardiovasc Electrophysiol 16: 394-396, 2005.

45. Sinner MF, Pfeufer A, Akyol M, Beckmann BM, Hinterseer M, Wacker A, Perz S, Sauter W, Illig T, Näbauer M, Schmitt C, Wichmann HE, Schömig A, Steinbeck G, Meitinger T and Kääb S: The non-synonymous coding IKr-channel variant KCNH2-K897T is associated with atrial fibrillation: results from a systematic candidate gene-based analysis of KCNH2 (HERG). Eur Heart J 29: 907-914, 2008.

46. Olson TM, Alekseev AE, Liu XK, Park S, Zingman LV, Bienengraeber M, Sattiraju S, Ballew JD, Jahangir A and Terzic A: Kv1.5 channelopathy due to KCNA5 loss-of-function mutation causes human atrial fibrillation. Hum Mol Genet 15: 2185-2191, 2006

47. Yang Y, Li J, Lin X, Yang Y, Hong K, Wang L, Liu J, Li L, Yan D, Liang D, Xiao J, Jin H, Wu J, Zhang Y and Chen YH: Novel KCNA5 loss-of-function mutations responsible for atrial fibrillation. J Hum Genet 54: 277-283, 2009.

48. Christophersen IE, Olesen MS, Liang B, Andersen MN, Larsen AP, Nielsen JB, Hauns $\emptyset$ S, Olesen SP, Tveit A, Svendsen JH and Schmitt N: Genetic variation in KCNA5: impact on the atrial-specific potassium current IKur in patients with lone atrial fibrillation. Eur Heart J 34: 1517-1525, 2013.

49. Olesen MS, Refsgaard L, Holst AG, Larsen AP, Grubb S, Hauns $\varnothing$ S, Svendsen JH, Olesen SP, Schmitt N and Calloe K: A novel KCND3 gain-of-function mutation associated with earlyonset of persistent lone atrial fibrillation. Cardiovasc Res 98: 488-495, 2013.

50. Xia M, Jin Q, Bendahhou S, He Y, Larroque MM, Chen Y, Zhou Q, Yang Y, Liu Y, Liu B, Zhu Q, Zhou Y, Lin J, Liang B, Li L, Dong X, Pan Z, Wang R, Wan H, Qiu W, Xu W, Eurlings P, Barhanin J and Chen Y: A Kir2.1 gain-of-function mutation underlies familial atrial fibrillation. Biochem Biophys Res Commun 332: 1012-1019, 2005.

51. Delaney JT, Muhammad R, Blair MA, Kor K, Fish FA, Roden DM and Darbar D: A KCNJ8 mutation associated with early repolarization and atrial fibrillation. Europace 14: 1428-1432, 2012.

52. Gollob MH, Jones DL, Krahn AD, Danis L, Gong XQ, Shao Q, Liu X, Veinot JP, Tang AS, Stewart AF, Tesson F, Klein GJ, Yee R, Skanes AC, Guiraudon GM, Ebihara L and Bai D: Somatic mutations in the connexin 40 gene (GJA5) in atrial fibrillation. N Engl J Med 354: 2677-2688, 2006.

53. Sun Y, Yang YQ, Gong XQ, Wang XH, Li RG, Tan HW, Liu X, Fang WY and Bai D: Novel germline GJA5/connexin40 mutations associated with lone atrial fibrillation impair gap junctional intercellular communication. Hum Mutat 34: 603-609, 2013.

54. Shi HF, Yang JF, Wang Q, Li RG, Xu YJ, Qu XK, FangWY, Liu X and Yang YQ: Prevalence and spectrum of GJA5 mutations associated with lone atrial fibrillation. Mol Med Rep 7: 767-774, 2013. 
55. Thibodeau IL, Xu J, Li Q, Liu G, Lam K, Veinot JP, Birnie DH, Jones DL, Krahn AD, Lemery R, Nicholson BJ and Gollob MH: Paradigm of genetic mosaicism and lone atrial fibrillation: physiological characterization of a connexin 43-deletion mutant identified from atrial tissue. Circulation 122: 236-244, 2010.

56. Hodgson-Zingman DM, Karst ML, Zingman LV, Heublein DM,Darbar D, Herron KJ, Ballew JD, de Andrade M, Burnett JC Jr and Olson TM: Atrial natriuretic peptide frameshift mutation in familial atrial fibrillation. $\mathrm{N} \mathrm{Engl}$ J Med 359: 158-165, 2008.

57. Darbar D, Kannankeril PJ, Donahue BS, Kucera G, Stubblefield T, Haines JL, George AL Jr and Roden DM: Cardiac sodium channel (SCN5A) variants associated with atrial fibrillation. Circulation 117: 1927-1935, 2008

58. Watanabe H, Darbar D, Kaiser DW, Jiramongkolchai K, Chopra S, Donahue BS, Kannankeril PJ and Roden DM: Mutations in sodium channel $\beta 1$ - and $\beta 2$-subunits associated with atrial fibrillation. Circ Arrhythm Electrophysiol 2: 268-275, 2009.

59. Olesen MS, Holst AG, Svendsen JH, Hauns $\varnothing$ S and TfeltHansen J: SCN1Bb R214Q found in 3 patients: 1 with Brugada syndrome and 2 with lone atrial fibrillation. Heart Rhythm 9 : 770-773, 2012.

60. Wang P, Yang Q, Wu X, Yang Y, Shi L, Wang C, Wu G, Xia Y, Yang B, Zhang R, Xu C, Cheng X, Li S, Zhao Y, Fu F, Liao Y, Fang F, Chen Q, Tu X and Wang QK: Functional dominantnegative mutation of sodium channel subunit gene SCN3B associated with atrial fibrillation in a Chinese GeneID population. Biochem Biophys Res Commun 398: 98-104, 2010.

61. Li RG, Wang Q, Xu YJ, Zhang M, Qu XK, Liu X, Fang WY and Yang YQ: Mutations of the SCN4B-encoded sodium channel $\beta 4$ subunit in familial atrial fibrillation. Int J Mol Med 32: 144-150, 2013.

62. Olesen MS, Andreasen L, Jabbari J, Refsgaard L, Hauns $\varnothing$ S, Olesen SP, Nielsen JB, Schmitt N and Svendsen JH: Very earlyonset lone atrial fibrillation patients have a high prevalence of rare variants in genes previously associated with atrial fibrillation. Heart Rhythm 11: 246-251, 2014.

63. Weeke P, Parvez B, Blair M, Short L, Ingram C, Kucera G, Stubblefield T, Roden DM and Darbar D: Candidate gene approach to identifying rare genetic variants associated with lone atrial fibrillation. Heart Rhythm 11: 46-52, 2014.

64. Mommersteeg MT, Christoffels VM, Anderson RH and Moorman AF: Atrial fibrillation: a developmental point of view. Heart Rhythm 6: 1818-1824, 2009.

65. Mahida S: Transcription factors and atrial fibrillation. Cardiovasc Res 101: 194-202, 2014

66. Schott JJ, Benson DW, Basson CT, Pease W, Silberbach GM Moak JP, Maron BJ, Seidman CE and Seidman JG: Congenital heart disease caused by mutations in the transcription factor NKX2-5. Science 281: 108-111, 1998.

67. Reamon-Buettner SM and Borlak J: NKX2-5: an update on this hypermutable homeodomain protein and its role in human congenital heart disease (CHD). Hum Mutat 31: 1185-1194, 2010.

68. Costa MW, Guo G, Wolstein O, Vale M, Castro ML, Wang L, Otway R, Riek P, Cochrane N, Furtado M, Semsarian C, Weintraub RG, Yeoh T, Hayward C, Keogh A, Macdonald P, Feneley M, Graham RM, Seidman JG, Seidman CE, Rosenthal N, Fatkin D and Harvey RP: Functional characterization of a novel mutation in NKX2-5 associated with congenital heart disease and adult-onset cardiomyopathy. Circ Cardiovasc Genet 6: 238-247, 2013

69. Garg V, Kathiriya IS, Barnes R, Schluterman MK, King IN, Butler CA, Rothrock CR, Eapen RS, Hirayama-Yamada K, Joo K, Matsuoka R, Cohen JC and Srivastava D: GATA4 mutations cause human congenital heart defects and reveal an interaction with TBX5. Nature 424: 443-447, 2003.

70. Zhou P, He A and Pu WT: Regulation of GATA4 transcriptional activity in cardiovascular development and disease. Curr Top Dev Biol 100: 143-169, 2012.

71. Yang YQ, Wang J, Liu XY, Chen XZ, Zhang W, Wang XZ, Liu X and Fang WY: Novel GATA4 mutations in patients with congenital ventricular septal defects. Med Sci Monit 18: CR344-CR350, 2012.

72. Yang YQ, Wang J, Liu XY, Chen XZ, Zhang W and Wang XZ: Mutation spectrum of GATA4 associated with congenital atrial septal defects. Arch Med Sci 9: 976-983, 2013.

73. Yang YQ, Gharibeh L, Li RG, Xin YF, Wang J, Liu ZM, Qiu XB, Xu YJ, Xu L, Qu XK, Liu X, Fang WY, Huang RT, Xue S and Nemer G: GATA4 loss-of-function mutations underlie familial tetralogy of fallot. Hum Mutat 34: 1662-1671, 2013.
74. Li RG, Li L, Qiu XB, Yuan F, Xu L, Li X, Xu YJ, Jiang WF, Jiang JQ, Liu X, Fang WY, Zhang M, Peng LY, Qu XK and Yang YQ: GATA4 loss-of-function mutation underlies familial dilated cardiomyopathy. Biochem Biophys Res Commun 439: 591-596, 2013.

75. Zhao L, Xu JH, Xu WJ, Yu H, Wang Q, Zheng HZ, Jiang WF, Jiang JF and Yang YQ: A novel GATA4 loss-of-function mutation responsible for familial dilated cardiomyopathy. Int J Mol Med 33: 654-660, 2014

76. Jiang JQ, Li RG, Wang J, Liu XY, Xu YJ, Fang WY, Chen XZ, Zhang W, Wang XZ and Yang YQ: Prevalence and spectrum of GATA5 mutations associated with congenital heart disease. Int J Cardiol 165: 570-573, 2013

77. Wei D, Bao H, Zhou N, Zheng GF, Liu XY and Yang YQ: GATA5 loss-of-function mutation responsible for the congenital ventriculoseptal defect. Pediatr Cardiol 34: 504-511, 2013.

78. Wei D, Bao H, Liu XY, Zhou N, Wang Q, Li RG, Xu YJ and Yang YQ: GATA5 loss-of-function mutations underlie tetralogy of fallot. Int J Med Sci 10: 34-42, 2013.

79. Huang RT, Xue S, Xu YJ, Zhou M and Yang YQ: Somatic GATA5 mutations in sporadic tetralogy of Fallot. Int J Mol Med 33: 1227-1235, 2014

80. Shi LM, Tao JW, Qiu XB, Wang J, Yuan F, Xu L, Liu H, Li RG, Xu YJ, Wang Q, Zheng HZ, Li X, Wang XZ, Zhang M, Qu XK and Yang YQ: GATA5 loss-of-function mutations associated with congenital bicuspid aortic valve. Int J Mol Med 33: 1219-1226, 2014.

81. Kodo K, Nishizawa T, Furutani M, Arai S, Yamamura E, Joo K, Takahashi T, Matsuoka R and Yamagishi H: GATA6 mutations cause human cardiac outflow tract defects by disrupting semaphorin-plexin signaling. Proc Natl Acad Sci USA 106: 13933-13938, 2009.

82. Zheng GF, Wei D, Zhao H, Zhou N, Yang YQ and Liu XY: A novel GATA6 mutation associated with congenital ventricular septal defect. Int J Mol Med 29: 1065-1071, 2012.

83. Wang J, Luo XJ, Xin YF, Liu Y, Liu ZM, Wang Q, Li RG, Fang WY, Wang XZ and Yang YQ: Novel GATA6 mutations associated with congenital ventricular septal defect or tetralogy of fallot. DNA Cell Biol 31: 1610-1617, 2012.

84. Huang RT, Xue S, Xu YJ and Yang YQ: Somatic mutations in the GATA6 gene underlie sporadic tetralogy of Fallot. Int J Mol Med 31: 51-58, 2013.

85. Yuan F, Zhao L, Wang J, Zhang W, Li X, Qiu XB, Li RG, Xu YJ, Xu L, Qu XK, Fang WY and Yang YQ: PITX2c loss-of-function mutations responsible for congenital atrial septal defects. Int J Med Sci 10: 1422-1429, 2013.

86. Wang J, Xin YF, Xu WJ, Liu ZM, Qiu XB, Qu XK, Xu L, Li X and Yang YQ: Prevalence and spectrum of PITX2c mutations associated with congenital heart disease. DNA Cell Biol 32: 708-16, 2013

87. Wei D, Gong XH, Qiu G, Wang J and Yang YQ: Novel PITX2c loss-of-function mutations associated with complex congenital heart disease. Int J Mol Med 33: 1201-1208, 2014.

88. Huang RT, Xue S, Xu YJ, Zhou M and Yang YQ: A novel NKX2.5 loss-of-function mutation responsible for familial atrial fibrillation. Int J Mol Med 31: 1119-1126, 2013.

89. Xie WH, Chang C, Xu YJ, Li RG, Qu XK, Fang WY, Liu X and Yang YQ: Prevalence and spectrum of Nkx2.5 mutations associated with idiopathic atrial fibrillation. Clinics (Sao Paulo) 68: 777-784, 2013

90. Yu H, Xu JH, Song HM, Zhao L, Xu WJ, Wang J, Li RG, Xu L, Jiang WF, Qiu XB, Jiang JQ, Qu XK, Liu X, Fang WY, Jiang JF and Yang YQ: Mutational spectrum of the NKX2-5 gene in patients with lone atrial fibrillation. Int J Med Sci 11: 554-563, 2014

91. Wang J, Sun YM and Yang YQ: Mutation spectrum of the GATA4 gene in patients with idiopathic atrial fibrillation. Mol Biol Rep 39: 8127-8135, 2012

92. Yang YQ, Wang J, Wang XH, Wang Q, Tan HW, Zhang M, Shen FF, Jiang JQ, Fang WY and Liu X: Mutational spectrum of the GATA5 gene associated with familial atrial fibrillation. Int J Cardiol 157: 305-307, 2012.

93. Wang XH, Huang CX, Wang Q, Li RG, Xu YJ, Liu X, Fang WY and Yang YQ: A novel GATA5 loss-of-function mutation underlies lone atrial fibrillation. Int J Mol Med 31: 43-50, 2013.

94. Gu JY, Xu JH, Yu H and Yang YQ: Novel GATA5 loss-offunction mutations underlie familial atrial fibrillation. Clinics (Sao Paulo) 67: 1393-1399, 2012.

95. Yang YQ, Wang XH, Tan HW, Jiang WF, Fang WY and Liu X: Prevalence and spectrum of GATA6 mutations associated with familial atrial fibrillation. Int J Cardiol 155: 494-496, 2012. 
96. Yang YQ, Li L, Wang J, Zhang XL, Li RG, Xu YJ, Tan HW, Wang XH, Jiang JQ, Fang WY and Liu X: GATA6 loss-offunction mutation in atrial fibrillation. Eur J Med Genet 55: 520-526, 2012.

97.Li J, Liu WD, Yang ZL and Yang YQ: Novel GATA6 loss-offunction mutation responsible for familial atrial fibrillation. Int J Mol Med 30: 783-790, 2012.

98. Yang YQ, Xu YJ, Li RG, Qu XK, Fang WY and Liu X: Prevalence and spectrum of PITX2c mutations associated with familial atrial fibrillation. Int J Cardiol 168: 2873-2876, 2013

99.Zhou YM, Zheng PX, Yang YQ, Ge ZM and Kang WQ: A novel PITX2c loss-of-function mutation underlies lone atrial fibrillation. Int J Mol Med 32: 827-834, 2013.

100. Wang J, Zhang DF, Sun YM and Yang YQ: A novel PITX2c loss-of-function mutation associated with familial atrial fibrillation. Eur J Med Genet 57: 25-31, 2014.

101. Qiu XB, Xu YJ, Li RG, Xu L, Liu X, Fang WY, Yang YQ and Qu XK: PITX2C loss-of-function mutations responsible for idiopathic atrial fibrillation. Clinics (Sao Paulo) 69: 15-22, 2014.

102. Biben C, Hatzistavrou T and Harvey RP: Expression of NK-2 class homeobox gene Nkx2-6 in foregut endoderm and heart. Mech Dev 73: 125-127, 1998.
103. Tanaka M, Schinke M, Liao HS, Yamasaki N and Izumo S: Nkx2.5 and Nkx2.6, homologs of Drosophila tinman, are required for development of the pharynx. Mol Cell Biol 21: 4391-4398, 2001.

104. Heathcote K, Braybrook C, Abushaban L, Guy M, Khetyar ME, Patton MA, Carter ND, Scambler PJ and Syrris P: Common arterial trunk associated with a homeodomain mutation of NKX2.6. Hum Mol Genet 14: 585-593, 2005.

105. Ta-Shma A, El-lahham N, Edvardson S, Stepensky P, Nir A, Perles Z, Gavri S, Golender J, Yaakobi-Simhayoff N, Shaag A, Rein AJ and Elpeleg O: Conotruncal malformations and absent thymus due to a deleterious NKX2-6 mutation. J Med Genet 51: 268-270, 2014

106. Pradhan L, Genis C, Scone P, Weinberg EO, Kasahara H and Nam HJ: Crystal structure of the human NKX2.5 homeodomain in complex with DNA target. Biochemistry 51: 6312-6319, 2012. 